\title{
Liver Lipoma
}

National Cancer Institute

\section{Source}

National Cancer Institute. Liver Lipoma. NCI Thesaurus. Code C5750.

A rare benign adipose tissue neoplasm of the liver. 